\title{
Auer Rod-Like Inclusions in B-Cell Prolymphocytic Leukemia
}

\section{B Hücreli Prolenfositik Lösemide Auer-Rod Benzeri İnklüzyonlar}

(D) Yantian Zhao, (D) Juan Lv

Beijing Chao-yang Hospital, Capital Medical University, Department of Clinical Laboratory, Beijing, China
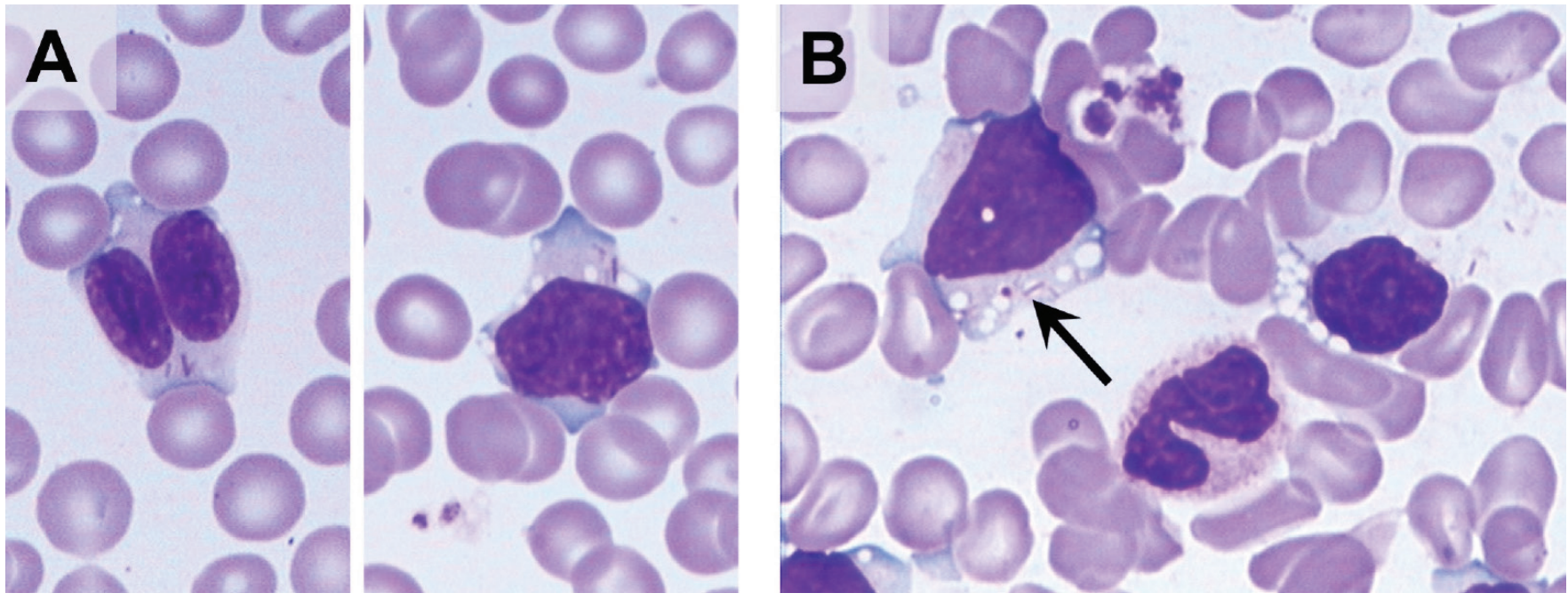

Figure 1. (A) Blood smears and (B) bone marrow smears demonstrating abnormal lymphocytes with Auer rod-like inclusions (1000x, Wright-Giemsa stain).

A 76-year-old male patient presented with increasing leukocytes in the past month. Laboratory investigation showed leukocytosis of $30.03 \times 10^{9} / \mathrm{L}$ (normal: $3.5-9.5 \times 10^{9} / \mathrm{L}$ ) with absolute lymphocytosis of $20.7 \times 10^{9} / \mathrm{L}$ (normal: $1.1-3.2 \times 10^{9} / \mathrm{L}$ ), with normal hemoglobin and platelet counts. Review of the peripheral blood smears (Figure 1A) and bone marrow smears (Figure 1B) demonstrated 64\% and 74.5\% prolymphocytes, respectively, with nucleoli, vacuoles, and Auer rod-like inclusions. The cytoplasmic inclusions were negative for myeloperoxidase by immunohistochemistry. Flow cytometry demonstrated a kapparestricted CD19 and CD20 immunoreactive B-cell population making up to $67.1 \%$ of cells and $93.1 \%$ of lymphocytes, with partial expression of slgM and lacking CD5, CD10, and CD23. No significant expression of CD38 was present. Although Auer rodlike inclusions were seen, there was no evidence of increased immature myeloid cells by flow cytometry or morphology. IgVH (FR1-FR3) mutation was not appreciable by molecular biology studies before or during this period. The patient achieved a partial response with chlorambucil treatment.

Auer rod-like inclusions have been reported in B-lineage malignancies like multiple myeloma $[1,2]$. Electron microscopy revealed these structures to be swollen mitochondria or immunoglobulins $[3,4]$, while classical Auer rods are formed by aggregation and concentration of peroxide granules in myeloid blasts.

Keywords: Auer rod-like inclusions, B-cell prolymphocytic leukemia, Lymphocytes

Anahtar Sözcükler: Auer-Rod benzeri inklüzyonlar, B hücreli prolenfositik lösemi, Lenfositler 


\section{Informed Consent: It was received.}

Conflict of Interest: The authors of this paper have no conflicts of interest, including specific financial interests, relationships, and/or affiliations relevant to the subject matter or materials included.

Financial Disclosure: This study was supported by the Beijing Municipal Administration of Hospitals' Youth Program (QML20150304) and the Beijing Municipal Administration of Hospitals' Clinical Medicine Development of Special Funding Support (ZYLX201811).

\section{References}

1. Sojitra $P, N a m$ MW, Omman R, Velankar MM. Auer rod-like inclusions in monoclonal B-cell lymphoproliferative disorder: a potential diagnostic pitfall. Pathol Int 2017;67:113-115.

2. Sylvia MT, Jacob SE, Basu D. Multiple myeloma with crystalline and Auer rod-like inclusions. Br J Haematol 2017;179:8.

3. Hutter G, Nowak D, Blau IW, Thiel E. Auer rod-like intracytoplasmic inclusions in multiple myeloma. A case report and review of the literature. Int J Lab Hematol 2009;31:236-240.

4. Qiufan Z, Shumei $X$, Xifeng D, Shuwen D, Huaquan W, Zonghong S. Auer rod-like inclusions in prolymphocytic leukemia. Clin Lab 2015;61:831-834. 